\title{
Evaluation of the behaviour of reinforced concrete beams repaired with glass fibre reinforced polymer (GFRP) using a damage variable
}

\author{
Rafael Nunes da Cunha, Kevin Mendonça Oliveira, Antônio Gabriel Lisboa Rego Brito, Camila \\ de Sousa Vieira, David Leonardo Nascimento de Figueiredo Amorim \\ Laboratory of Building Materials and Structures, Post-graduation Programme in Civil Engineering, Department of Civil \\ Engineering, Federal University of Sergipe, São Cristóvão, Brazil \\ rafael.cunba@ctec.ufal.br, bttp://orcid.org/0000-0003-2503-6758 \\ kevin.zero@hotmail.com; bttp://orcid.org/0000-0002-1685-3636 \\ gabriel.lisboa.eng@gmail.com; http://orcid.org/0000-0002-2075-3208 \\ milavieira@gmail.com, bttp://orcid.org/0000-0002-5371-191X \\ davidnf@academico.ufs.br, bttp:/ / orcid.org/0000-0002-9233-3114
}

ABSTRACT. The use of fibre reinforced polymers (FRP) for increasing the strength of reinforced concrete (RC) structures became a usual method. FRP presents easy application and demands low space and provide significant strength increase. Usually, the decision for FRP use is made in terms of applied loads and deflections. However, such quantities can vary significantly depending on the characteristics of the structural element e.g. span, effective depth and concrete resistance. Therefore, this paper aims to present an alternative control variable to analyse the behaviour of RC beams repaired with glass fibre reinforced polymer (GFRP), called damage. Such damage variable accounts for concrete cracking and it was experimentally measured before and after the application of GFRP. Note that the application of GFRP increased the ultimate load for all repaired beams. The damage values of such beams also increased when collapse was reached. Furthermore, it was observed that the collapse mechanism shifted to shear and did not occurred the failure of the GFRP.

KEYWORDS. Glass fibre reinforced polymer; Repair; Reinforced concrete beams; Damage.

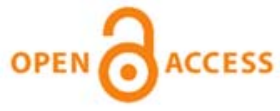

Citation: Cunha, R. N., Oliveira, K. M., Brito, A. G. L. R., Vieira, C. S., Amorim, D. L. N. F., Evaluation of the behaviour of reinforced concrete beams repaired with glass fibre reinforced polymer (GFRP) using a damage variable, Frattura ed Integrità Strutturale, 57 (2021) 82-92.

Received: 05.04 .2021

Accepted: 19.05.2021

Published: 01.07.2021

Copyright: (C) 2021 This is an open access article under the terms of the CC-BY 4.0, which permits unrestricted use, distribution, and reproduction in any medium, provided the original author and source are credited.

\section{INTRODUCTION} as well as changes of loading due to alteration of the structure use. Structural strengthening consists in intervention at an existing structure, increasing its loading capacity before reaching its limit state, while repair is the 
reestablishment of use and security of a previously damaged structure. RC structures degrade over time due to multiple causes, from natural aging to accidents, even due to design errors. The most apparent symptoms of problems in RC structures are cracks, deformations, exposition and corrosion of the steel bars.

The methods of strengthening and repair of reinforced concrete structures depend on the accurate analysis of the causes that made them necessary and the detailed study of the produced effects. After this definition, the choice of the appropriate technique is made, including the materials and equipment to be used [1]. Traditional techniques of structural strengthening, among which the increase of the cross section and the use of metallic profiles stands out, present disadvantages such as the increase of the structure dead load, change in stiffness, and the need to handle heavy metal components [2]. In order to circumvent such disadvantages, new strengthening and repair techniques were studied and created, some of which use composite materials which have a high strength-to-weight ratio, among other desirable properties [3-7].

One of the most applied strengthening strategies is the use of fibres that can be of different materials e.g. steel and glass. The fibres may be used in the concrete mixture step, providing higher resistance and ductility [8-9]. Furthermore, fibre reinforced polymers (FRP) may be used to repair structural elements that suffered total or partial collapses [10]. Choobbor et al. [11] evaluated the bending performance of reinforced concrete beams strengthened with hybrid carbon and basalt fibre reinforced polymer (CFRP/BFRP) composite sheets. Nine beams were tested with different combinations of CFRP and BFRP sheets and the test results indicated clear improvements in the load-carrying capacity and ductility of the strengthened specimens. An experimental investigation was conducted by Ali et al. [12] to examine the flexural capacity of continuous reinforced concrete beams with three spans strengthened or repaired by bonding CFRP or glass fibre reinforced polymers (GFRP) sheets. Experimental tests with monotonic loading were carried out by varying damaged level of the beams, composite material type and strengthening thickness. The results showed that the ultimate bending moment of the beam can be improved. A study of the behaviour of reinforced concrete beam-column joints repaired with externally bonded FRP or Fibre Reinforced Cementitious Matrix (FRCM) composites were made by Faleschini et al. [13]. Concrete specimens suffered significant damage, then were repaired. The same loading history was applied to the repaired specimens to identify the contribution of the externally-bonded composites to the overall behaviour of the repaired specimens.

Usually, the variables controlling the decision-making process for repair or strength structural elements are, among others, applied loads, bending moments, shear forces and deflections. The main issue is that those quantities vary significantly for each practical engineering problem. As an alternative, the Lumped Damage Mechanics (LDM) defines a damage variable that characterises the concrete cracking [14]. Therefore, it is possible to affirm that the same damage value means collapse for a RC beam in conventional buildings and bridges. LDM models were suitably developed and applied for RC structures in several conditions, such as buildings under seismic loads [15-19], tunnel linings [20-22] and even impact loaded beams [23-25].

In this paper, the behaviour of reinforced concrete beams pre-loaded with different ultimate load ratios and repaired with glass fibre reinforced polymer is investigated, using such damage variable. The repaired beams were subjected to a cyclic flexural test to assess the influence of the glass fibre fabric on ultimate strength, maximum damage and failure mode.

\section{EXPERIMENTAL PROGRAMME}

1 he four reinforced concrete beams utilised in the experiments were designed to collapse by bending moment. The beams cross section dimensions are $10 \mathrm{~cm}$ of base and $15 \mathrm{~cm}$ of height, while its total length is equal to $70 \mathrm{~cm}$ and the span (distance between supports) is $60 \mathrm{~cm}$. Longitudinal reinforcement is comprised of two steel bars with 10 $\mathrm{mm}$ of diameter, which represents area of steel equal to $1.57 \mathrm{~cm}^{2}$, and yield stress of $500 \mathrm{MPa}$. Transversal reinforcement is formed by steel stirrups of yield stress of $600 \mathrm{MPa}$ and $5.0 \mathrm{~mm}$ of diameter, which is equivalent of $2.12 \mathrm{~cm}^{2} / \mathrm{cm}$ of area of steel. Fig. 1 shows the reinforcement of one of the beams.

The cement used to manufacture the beams was CP II Z-32 (Portland cement composed with pozzolanic materials and compressive strength at 28 days equal to $32 \mathrm{MPa}$ ) from a Brazilian brand whose specific mass is $3.03 \mathrm{~g} / \mathrm{cm}^{3}$ determined according to technical standard NBR 16605 [26]. Tab. 1 presents the aggregates characterisation.

One of the casted beams is experimented up to collapse and the other ones were reinforced with unidirectional glass fibre fabric VEW130 (Fig. 2), after certain ultimate load ratios. Such reinforcement was manufactured in the USA and it was applied with a Brazilian brand epoxy resin. The data of the glass fibre, provided by the manufacturer, is described in Tabs. 2,3 and 4 .

The dosage of the concrete mixture followed the ACI/ABCP method [31], aiming to obtain a characteristic compressive strength $\left(\mathrm{f}_{\mathrm{ck}}\right.$ ) equal to $30 \mathrm{MPa}$. Thus, was adopted the following proportion of cement, sand, gravel 0 and gravel 1: 1:2.21:1.30:1.30. The water-cement ratio was 0.52 . The result of the slump test for the mixture was $120 \mathrm{~mm}$, measured 
according to the technical standard NBR NM 67 [32]. In addition to the beams, two specimens of $200 \mathrm{~mm}$ of height and $100 \mathrm{~mm}$ of diameter were moulded to determine the compressive strength of concrete in accordance with the technical standards NBR 5738 [33] and NBR 5739 [34].

The four beams were demoulded 24 hours after casting and cured submerged during 28 days. After curing, the reference beam (RB) was subjected to a cyclic 3-point bending test with displacement control (Fig. 3), with test velocity of 1 mm/s. In order to obtain the maximum strength, the beam was loaded until to rupture, in 14 loading cycles. Then, on the remaining three beams, loads equivalent to 100\% (beam \#1), 80\% (beam \#2) and 60\% (beam \#3) of the maximum force were applied, with 7, 5 and 5 loading cycles, respectively. The tests were performed with universal testing machine EMIC/INSTRON model DL 2000.

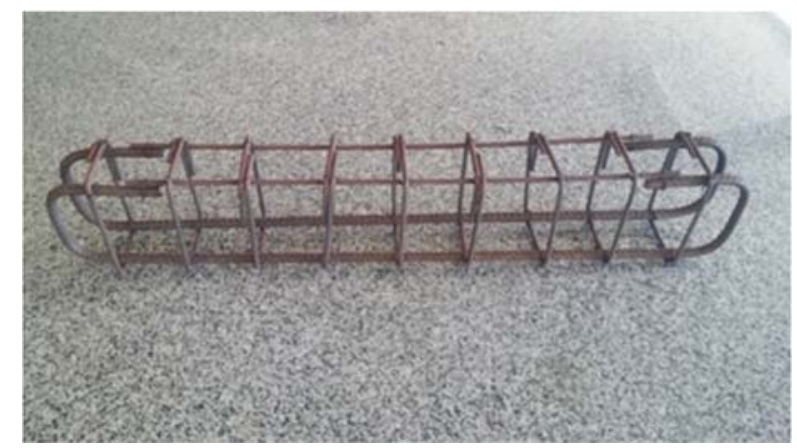

Figure 1: Reinforcement of the beam.

\begin{tabular}{cccc}
\hline Aggregate & Characteristic & Results & Technical standard \\
& Specific mass $\left(\mathrm{g} / \mathrm{cm}^{3}\right)$ & 2.64 & NBR NM 52 [27] \\
Sand & Maximum diameter $(\mathrm{mm})$ & 4.8 & NBR NM 248 [28] \\
& Fineness modulus & 2.69 & NBR NM 248 [28] \\
& Specific mass $\left(\mathrm{g} / \mathrm{cm}^{3}\right)$ & 2.65 & NBR NM 53 [29] \\
Gravel 0 & Maximum diameter $(\mathrm{mm})$ & 9.5 & NBR NM 248 [28] \\
& Specific mass $\left(\mathrm{g} / \mathrm{cm}^{3}\right)$ & 2.65 & NBR NM 53 [29] \\
Gravel 1 & Maximum diameter $(\mathrm{mm})$ & 19.0 & NBR NM 248 [28] \\
\hline
\end{tabular}

Table 1: Aggregates characterisation.

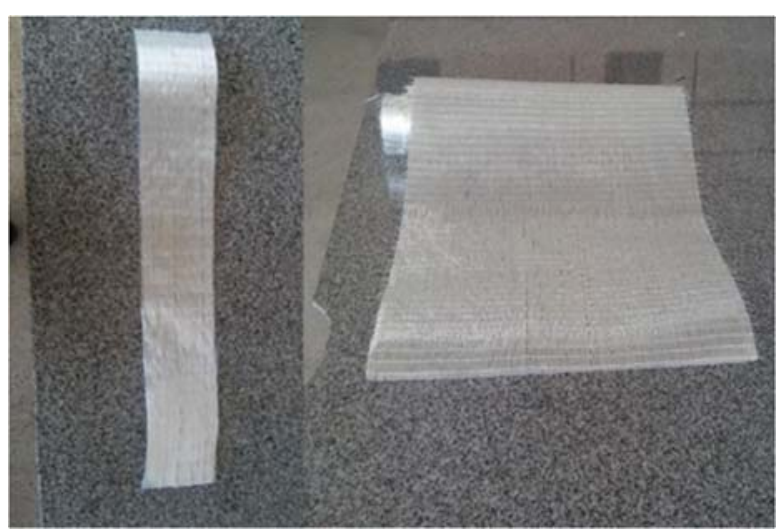

Figure 2: Unidirectional glass fibre fabric.

\begin{tabular}{cc}
\hline Property & Results \\
Density $\left(\mathrm{g} / \mathrm{cm}^{3}\right)$ & 1.85 \\
Fibre percentage $(\% /$ peso $)$ & 69 \\
Thickness $(\mathrm{mm})$ & 0.02 \\
\hline
\end{tabular}

Table 2: Physical properties of fibreglass [30]. 


\begin{tabular}{cc}
\hline Maximum stress & Results $(\mathrm{MPa})$ \\
Longitudinal traction & 682.58 \\
Longitudinal compression & 682.58 \\
Transverse traction & 220.63 \\
Transverse compression & 220.63 \\
In-plane shear & 103.42 \\
Longitudinal bending & 689.48 \\
Transverse bending & 206.84 \\
\hline
\end{tabular}

Table 3: Resistance of fibreglass [30].

\begin{tabular}{cc}
\hline Elasticity moduli & Results $(\mathrm{MPa})$ \\
$\mathrm{E}_{\mathrm{x}}$ & 36.13 \\
$\mathrm{E}_{\mathrm{y}}$ & 11.03 \\
$\mathrm{G}_{\mathrm{xy}}$ & 5.24 \\
$\mathrm{E}_{\mathrm{x}, \mathrm{bending}}$ & 34.34 \\
$\mathrm{E}_{\mathrm{y}, \mathrm{bending}}$ & 10.48 \\
\hline
\end{tabular}

Table 4: Elasticity moduli of fibreglass.

After the bending tests, the beams were reinforced. Initially, a layer of epoxy resin was applied to serve as an interface between the concrete and the glass fibre fabric. After that, the fibre was applied on the entire longitudinal section and, finally, another layer of resin was added (Fig. 4). The resin cured after a week and then further tests were made.

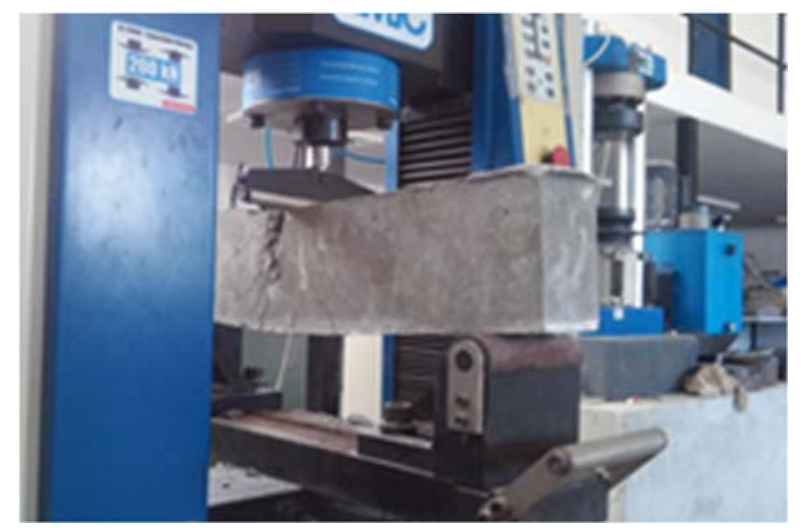

Figure 3: Beam during the test.

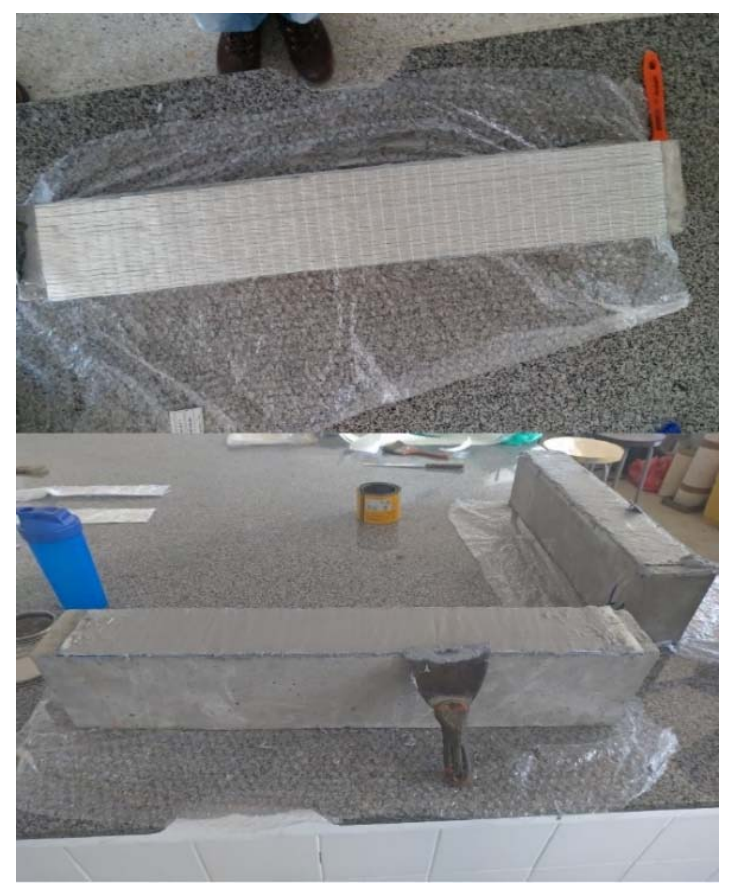

Figure 4: Glass fibre application. 
After the glass fibre reinforcement of the beams, new cyclic 3-point bending tests were made, which were applied 7, 6 and 6 loading cycles in the beams \#1, \#2 and \#3, respectively. This time, all three beams were loaded to collapse in order to visualise its behaviour when compared to the reference beam, which had no fibre-reinforcement.

\section{EXPERIMENTAL DAMAGE MEASUREMENT}

7 he experimental response of the beams can be given by:

$$
P=Z(D)\left(w-w_{p}\right)
$$

where $P$ is the applied load, $w$ is the total deflection, $w_{p}$ is the plastic/permanent deflection that measures the steel reinforcement yielding and $Z(D)$ is the current stiffness of the beam (Fig. 5), considering concrete cracking, given by:

$$
Z(D)=(1-D) Z_{0}
$$

being $Z_{0}$ the initial stiffness, i.e. when the concrete is intact, and $D$ the damage variable which accounts for the concrete cracking.

Thus, the damage variable can be measured by experiments using the following relation:

$$
D=1-\frac{Z(D)}{Z_{0}}
$$

Mathematically, the damage variable is nil if there is no cracks in concrete and tends to one if the beam is about to split in two parts. However, despite this mathematical definition, the collapse is reached for damage values smaller than one [35]. According to Lemaitre and Chaboche [35], most materials fail for damage values between 0.20 and 0.50 . For reinforced concrete beams, the bearing capacity is usually achieved for damage values around 0.60 [14]. Such value is defined as ultimate damage $\left(D_{u}\right)$ and can be calculated by the classic RC theory or experimentally measured. In both cases, such value is associated to the bearing capacity of the element.

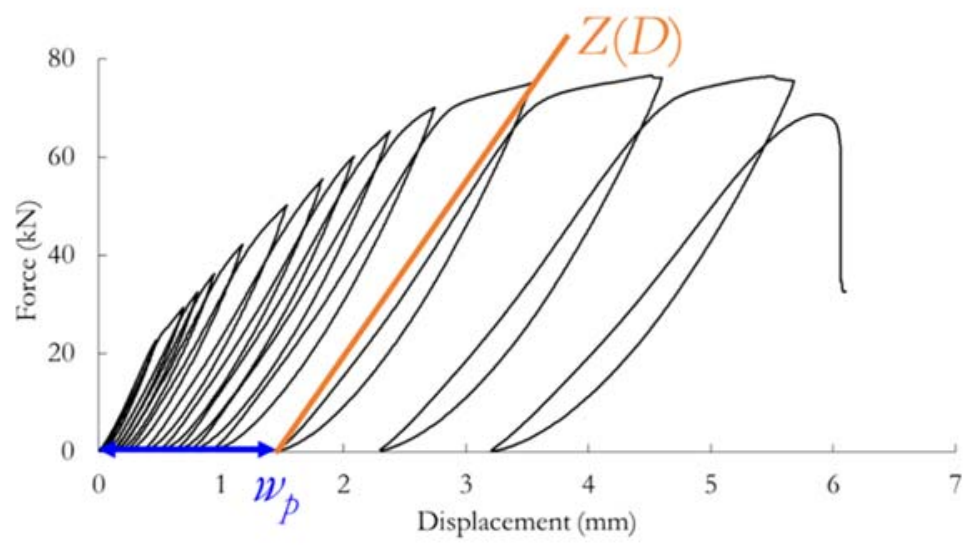

Figure 5: Graphical representation of damage measurement.

\section{RESULTS}

7 he cyclic flexural test of the reference beam is presented in Fig. 6. The bearing capacity of the beam is $76.62 \mathrm{kN}$ and its ultimate damage is 0.53 . The damage for each cycle of the reference beam and the repaired beams \#1, \#2 and \#3 are depicted in Fig. 7 in terms of the bending moment at the centre of the beam. 
Before repair, the beam \#1 (Fig. 8) was loaded up to $76.10 \mathrm{kN}$ and the resulting damage was 0.45 . After repair, the beam \#1 was loaded up to collapse, which occurred with the applied force of $83.98 \mathrm{kN}$ and the damage at the end of the test was 0.57. Beam \#2 achieved 0.37 of damage before repair, which consists of $61.01 \mathrm{kN}$ of applied force. When repaired, the beam \#2 (Fig. 9) reached $86.43 \mathrm{kN}$ of maximum force and 0.52 of measured damage. Finally, beam \#3 (Fig. 10) was loaded up to $46.06 \mathrm{kN}$ and the damage at that point was 0.30 . After repaired, such beam presented maximum bearing capacity of $83.98 \mathrm{kN}$ and the damage was 0.50 when the test was concluded. The values of maximum force and damage for all beams are summarised in Tab. 5.

An important observation during the experiments is that the collapse mechanism of the repaired beams shifted to shear (Fig. 11). Note that the repaired beams presented similar bearing capacity, which is close to the shear strength of such beams, calculated as $F_{s}=85.54 \mathrm{kN}$ (4) using the Brazilian Standard Code NBR 6118 [36]:

$$
F_{s}=0.27\left(1-\frac{f_{c k}}{250}\right) f_{c k} b_{w} d
$$

being $b_{w}$ the basis and $d$ the effective height $(10 \mathrm{~cm})$.

The behaviour shift is evident for beam \#1 since there are cracks at the mid-span characterising flexure failure. These cracks appeared in the pre-loading step i.e. when the beam was without GFRP. Then, after repair, such beam presented severe shear cracks (Fig. 11). The mid-span cracks at the beams \#2 and \#3 are not severe, since both were repaired after submitted to loads considerably smaller than the collapse force. However, in these last two beams, the shear cracks occurred as well.

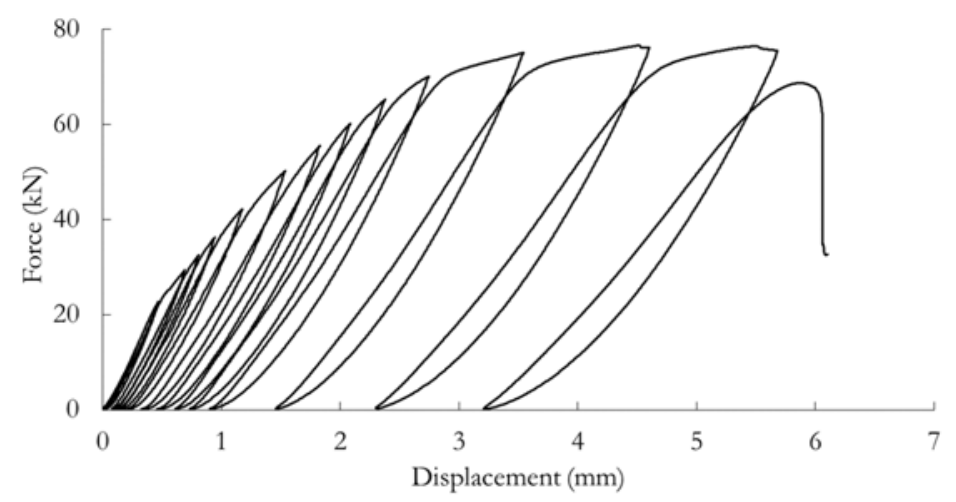

Figure 6: Force-displacement response of the reference beam.

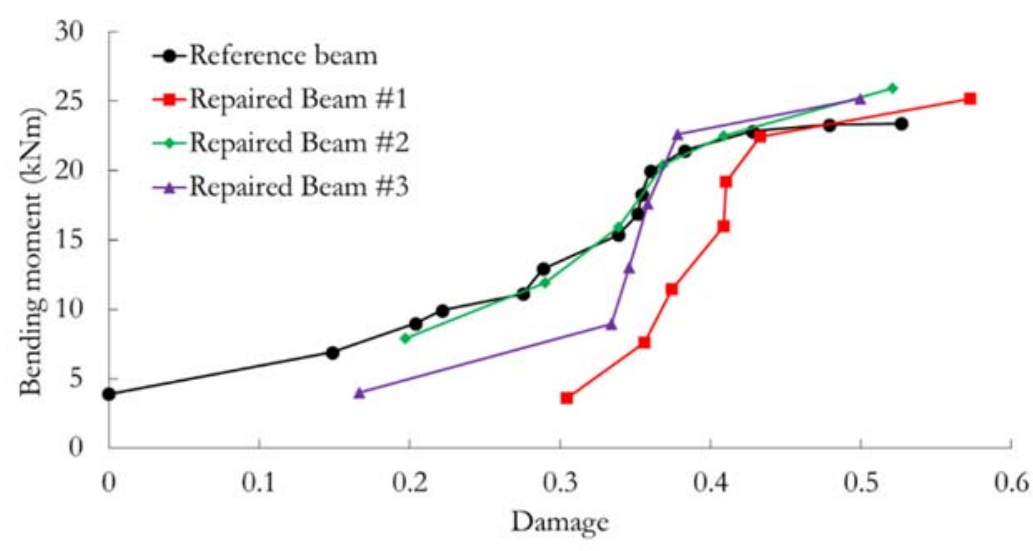

Figure 7: Bending moment and damage values at each cycle. 


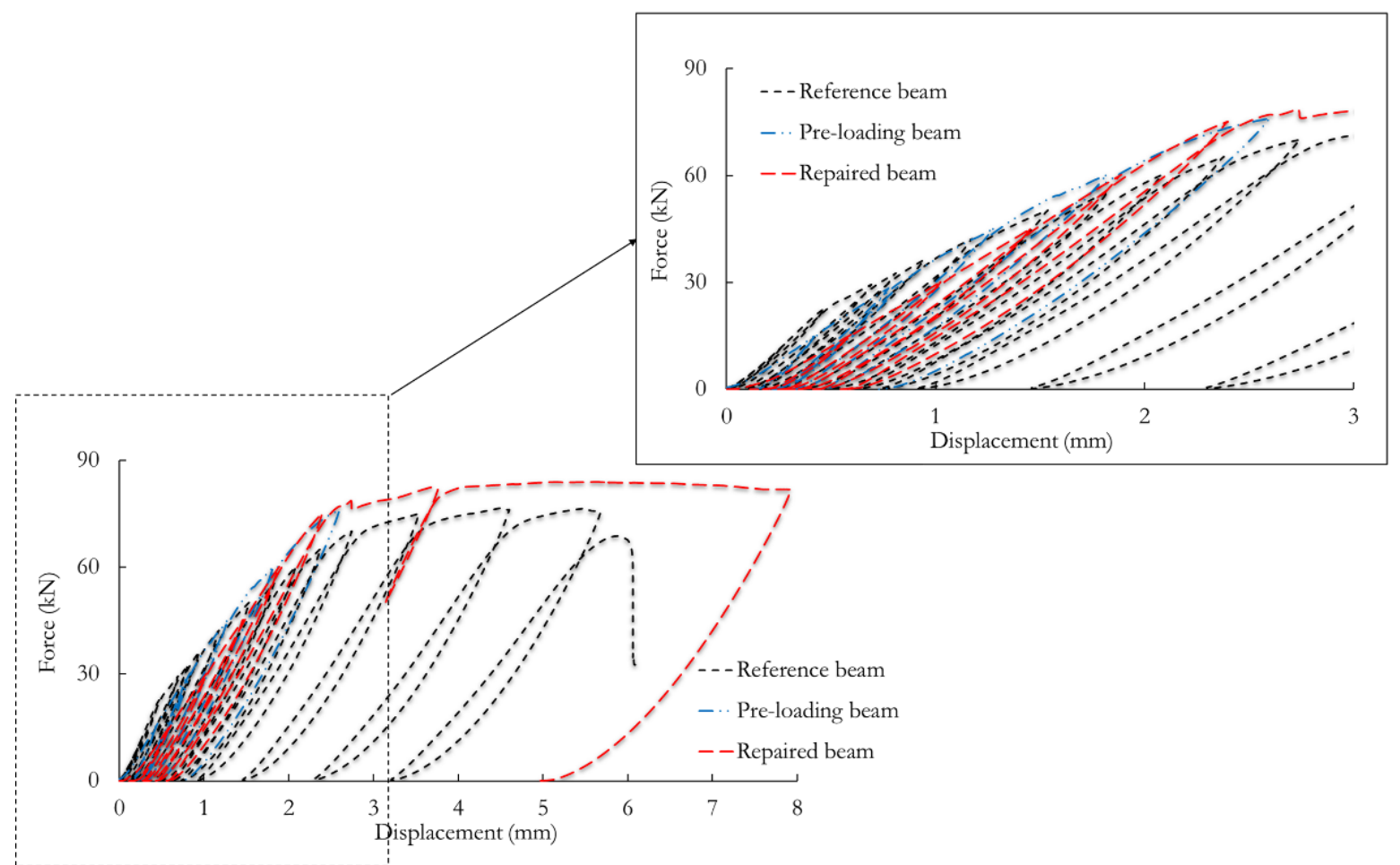

Figure 8: Beam \#1.

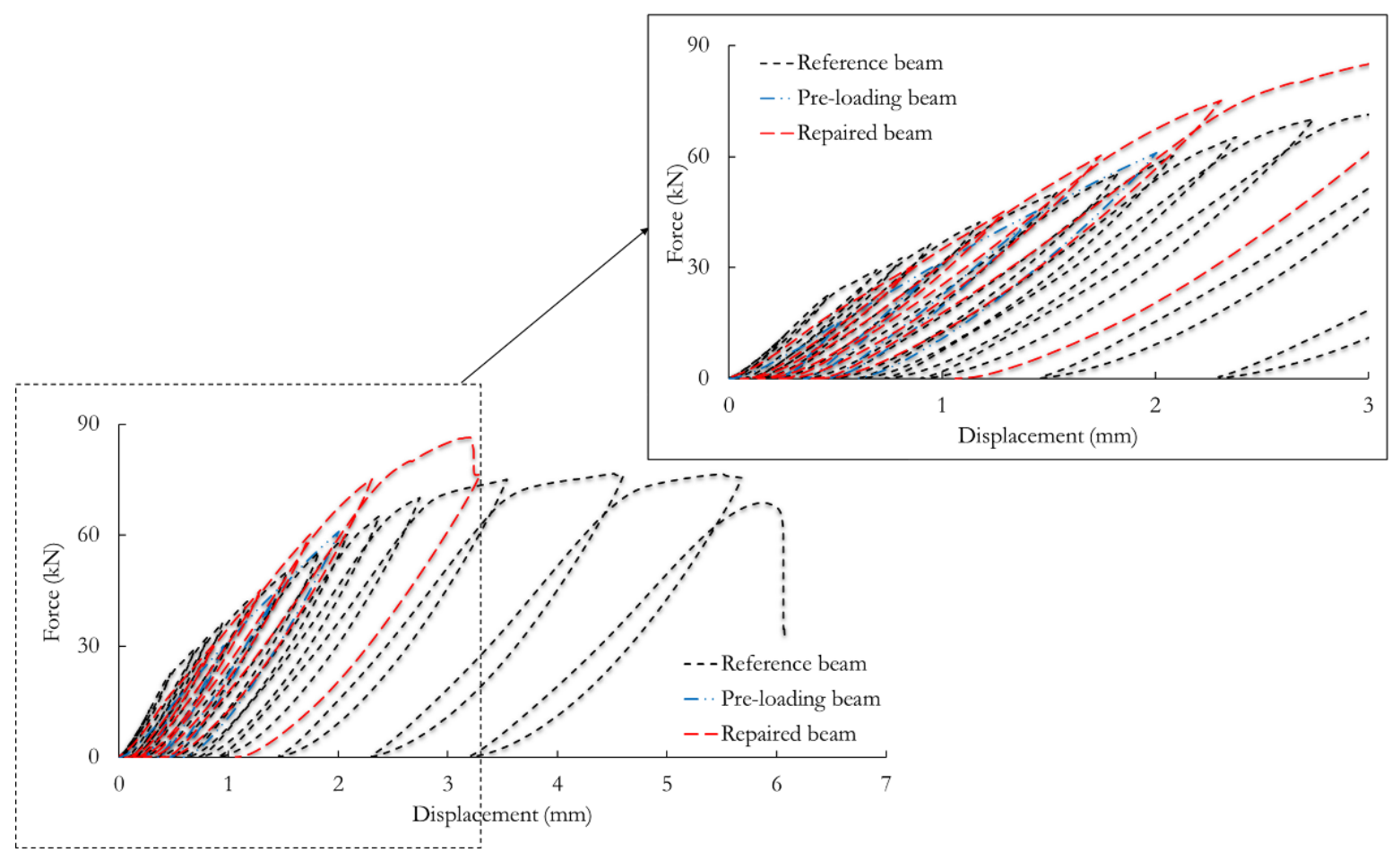

Figure 9: Beam \#2. 


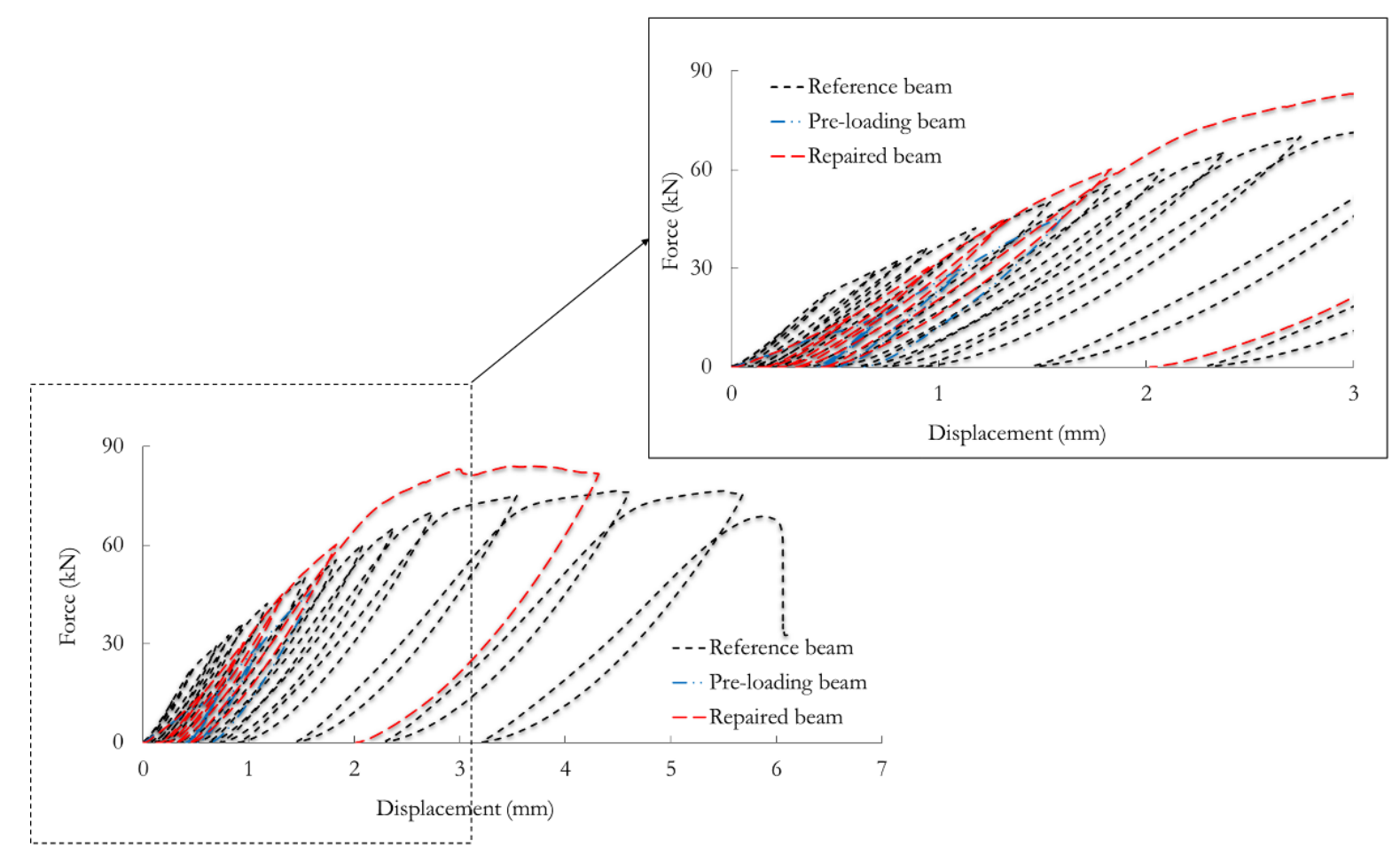

Figure 10: Beam \#3.

\begin{tabular}{ccccc}
\hline Beam & $\begin{array}{c}\text { Maximum force } \\
\text { before repair }(\mathrm{kN})\end{array}$ & $\begin{array}{c}\text { Maximum damage } \\
\text { before repair }\end{array}$ & $\begin{array}{c}\text { Maximum force } \\
\text { after repair }(\mathrm{kN})\end{array}$ & $\begin{array}{c}\text { Maximum damage } \\
\text { after repair }\end{array}$ \\
Reference & 76.62 & 0.53 & $\backslash$ & $\checkmark$ \\
$\# 1$ & 76.10 & 0.45 & 83.98 & 0.57 \\
$\# 2$ & 61.01 & 0.37 & 86.43 & 0.52 \\
$\# 3$ & 46.06 & 0.30 & 83.98 & 0.50 \\
\hline
\end{tabular}

Table 5: Maximum force and damage values before and after repair.

\section{CONCLUSION}

his paper aimed to investigate the behaviour of reinforced concrete beams, which were repaired with glass fibre reinforced polymer (GFRP), measuring the integrity of the beams with the damage variable.

At first, it was obtained the results of displacement and damage for the reference beam (without GFRP), for a comparison with the other ones. The reference beam presented collapse for 0.53 of damage. Such value is considered the ultimate damage for these beams i.e. the damage value when the load bearing capacity is reached. The analysed beams were previously loaded with a percentage of the collapse load, obtained in the reference beam, equal to 100\% (beam \#1), 80\% (beam \#2) and 60\% (beam \#3). After the repair using GFRP, these three beams were reloaded up to collapse.

Note that, for all repaired beams, the ultimate load increased in comparation with the obtained for reference beam, even when preloaded with $100 \%$ of its strength. Besides that, when analysing the failure mode, it is possible to observe that the collapse mechanism of the repaired beams shifted to shear, without occurring the failure of the GFRP. The damage values for the repaired beams varied from 0.50 (beam \#3) to 0.57 (beam \#1). Such range is near to values considered as collapse for RC beams without FRP. However, since those beams were repaired by GFRP and the collapse mechanism shifted to shear, further studies are needed to determine the ultimate damage at these conditions.

For future works, it is recommended to carry out an extensive experimental campaign as an attempt to characterise for which damage values the RC beams should be reinforced/repaired with GFRP and other techniques. 


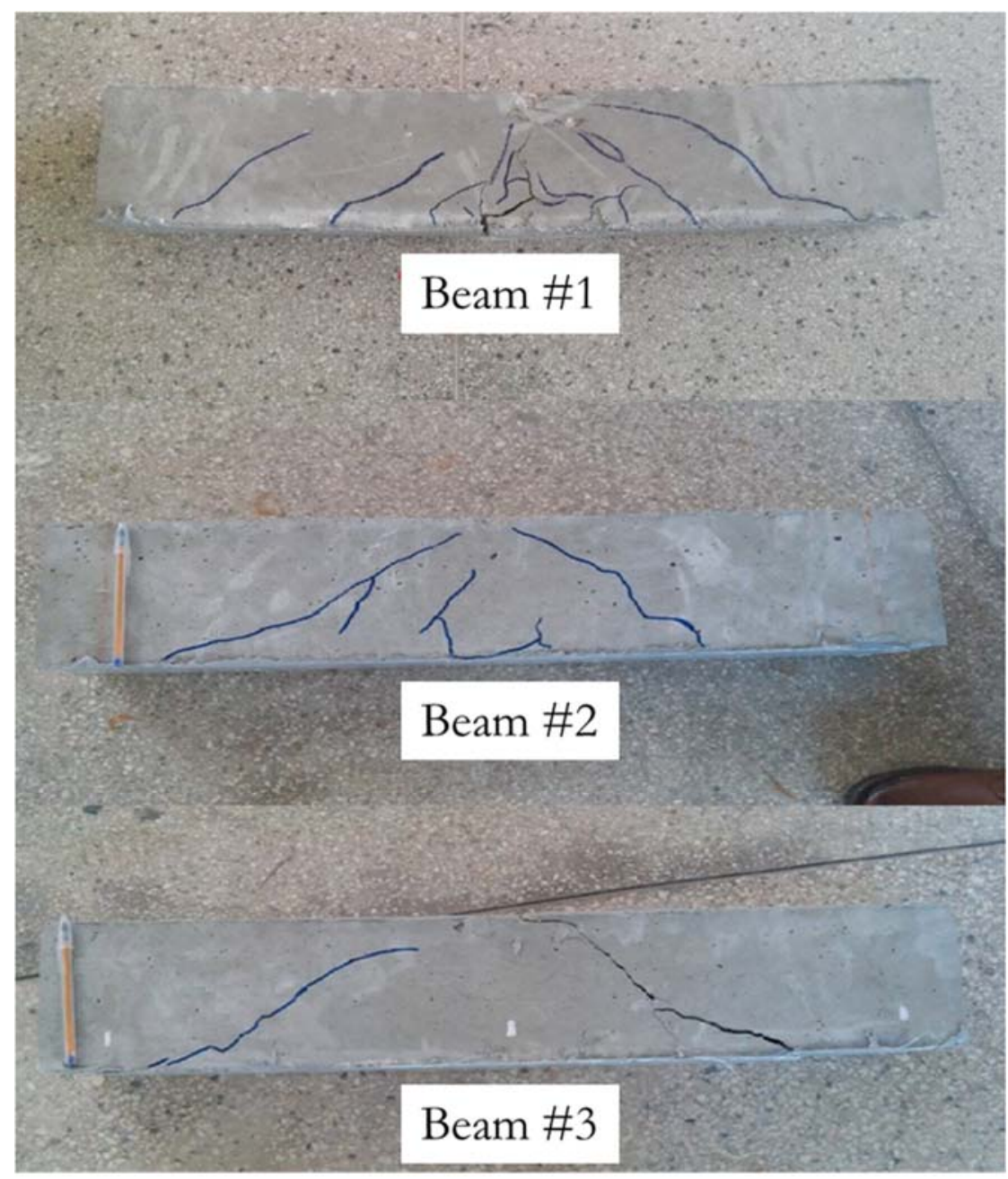

Figure 11: Cracking pattern of the repaired beams.

\section{ACKNOWLEDGEMENTS}

7 he authors acknowledge the financial support from FAPITEC/CAPES (Fundação de Apoio à Pesquisa e a Inovação Tecnológica do Estado de Sergipe/Coordenação de Aperfeiçoamento de Pessoal de Nivel Superior) for the PROEF grant for the Post-Graduation Programme in Civil Engineering of the Federal University of Sergipe (PROEC/UFS), to the grant PROAP 47481/2018-82, provided to the Post-Graduation Programme in Civil Engineering (PROEC/UFS) by CAPES (Coordenação de Aperfeiçoamento de Pessoal de Nivel Superior), to Laboratory of Building Materials and Structures (LAMCE/UFS) and to Laboratory of Mathematical Modelling in Civil Engineering (LAMEC/UFS) for the physical support during the development of this work. The first author acknowledges CAPES for the financial support of his M.Sc. studies. The third author acknowledges FAPITEC for the financial support of his M.Sc. studies. The fourth author acknowledges PNPD/CAPES for the financial support of her Postdoc studies.

\section{REFERENCES}

[1] Souza, V.C.M. and Ripper, T. (2009). Patologia, recuperação e reforço de estruturas de concreto, São Paulo, PINI.

[2] Gonzalez-Libreros, J.H., Sneed, L.H., D’Antino, T. and Pellegrino, C. (2017). Behavior of RC beams strengthened in shear with FRP and FRCM composites, Eng Struct, 150, pp. 830-842. DOI: 10.1016/j.engstruct.2017.07.084. 
[3] Micota, D., Isaincu, A. and Marsavina, L. (2021). Micromechanical modeling of glass fiber reinforced plastic material, Materials Today: Proceedings. DOI: 10.1016/j.matpr.2020.12.919.

[4] Attari, N., Amziane, S. and Chemrouk, M. (2012). Flexural strengthening of concrete beams using CFRP, GFRP, and hybrid FRP sheets, Constr Build Mater, 37, pp. 746-757. DOI: 10.1016/j.conbuildmat.2012.07.052.

[5] Ebead, U. A., Shrestha, K. C., Afzal, M. S., Refai, A. E. and Nanni, A. (2016). Effectiveness of fabric-reinforced cementitious matrix in strengthening reinforced concrete beams, J Compos Constr, 21(2), pp. 04016084. DOI: 10.1061/(ASCE)CC.1943-5614.0000741.

[6] Pino, V., Nanni, A., Arbodela, D. and Roberts-Wollmann, C. (2016). Repair of damaged prestressed concrete girders with FRP and FRCM composites, J Compos Constr, 21(3), pp. 04016111. DOI: 10.1061/(asce)cc.1943-5614.0000773.

[7] Ajwad, A., Aqdas, A., Khan, M.A., Abbas, A. and Baig, Z. (2019). Using carbon fibre reinforced polymer strips for recuperation of originally fissured concrete beams, Pak J E T, 2(1), pp. 36-40.

DOI: $10.51846 /$ pakistan $\% 20 j \% 20$ engg $\% 20 \& \% 20$ tech.v2i1.

[8] Akbari, J. and Abed, A. (2020) Experimental Evaluation of Effects of Steel and Glass Fibers on Engineering Properties of Concrete: Engineering Properties of Concrete, Frattura ed Integrità Strutturale, 14(54), pp. 116-127.

DOI: $10.3221 /$ IGF-ESIS.54.08.

[9] Triantis, D., Tsaousi, D. K., Stavrakas, I., Pasiou, E. D., Douvis, P. and Kourkoulis, S. K. (2020). Electric and acoustic activity in notched fiber-reinforced concrete beams under three-point bending. Materials Today: Proceedings, 32, 148155. DOI: $10.1016 /$ j.matpr.2020.03.785.skype

[10] Carpinteri, A., Lacidogna, G. and Manuello, A. (2007). An Experimental Study on Retrofitted Fiber-Reinforced Concrete Beams using AE, Fracture Mechanics of Concrete and Concrete Structures, Taylor \& Francis, London, 2, 1061-1068.

[11] Choobbor, S.S., Hawileh, R.A., Abu-Obeidah, A. and Abdalla, J.A. (2019). Performance of hybrid carbon and basalt FRP sheets in strengthening concrete beams in flexure, Compos Struct, 227, pp. 111337. DOI: $10.1016 /$ j.compstruct.2019.111337.

[12] Ali, H., Assih, J., and Li, A. (2021). Flexural capacity of continuous reinforced concrete beams strengthened or repaired by CFRP/GFRP sheets, Int J Adhes Adhes, 104, pp. 102759. DOI: 10.1016/j.ijadhadh.2020.102759.

[13] Faleschini, F., Gonzalez-Libreros, J., Zanini, M.A., Hofer, L., Sneed, L. and Pellegrino, C. (2019). Repair of severelydamaged RC exterior beam-column joints with FRP and FRCM composites, Compos Struct, 207, pp. $352-363$. DOI: $10.1016 /$ j.compstruct.2018.09.059.

[14] Flórez-López, J., Marante, M.E., Picón, R. (2015). Fracture and damage mechanics for structural engineering of frames: State-of-the-art industrial applications, Engineering Science Reference. ISBN: 978-1466663794.

[15] Flórez-López J. (1993) Modelos de daño concentrado para la simulación del colapso de pórticos planos. Rev Int Mét Num Cálc Dis Ing., 9(2), pp. 123-139.

[16] Cipollina, A., López-Inojosa, A., Flórez-López, J. (1995). A simplified damage mechanics approach to nonlinear analysis of frames, Comput. Struct., 54(6), pp. 1113-26, DOI: 10.1016/0045-7949(94)00394-I.

[17] Perdomo, M.E., Ramírez, A., Flórez-López, J. (1999). Simulation of damage in RC frames with variable axial forces, Earthq. Eng. Struct. Dyn., 28(3), pp. 311-28, DOI: 10.1002/(sici)1096-9845(199903)28:3<311::aid-eqe819>3.0.co;2-d.

[18] Rajasankar J, Iyer NR, Prasad AP. (2009). Modelling inelastic hinges using CDM for nonlinear analysis of reinforced concrete frame structures. Comput Concr.,6(4), pp. 319-41, DOI: 10.12989/cac.2009.6.4.319.

[19] Teles DVC, Cunha RN, Amorim DLNF, Picón R, Flórez-López J. (2021). Parametric study of dynamic behaviour of RC dual system design with the Brazilian Standard Code using the Lumped Damage Model. J Braz Soc Mech Sci, approved paper: forthcoming.

[20] Amorim, D.L.N.F., Proença, S.P.B., Flórez-López, J. (2013). A model of fracture in reinforced concrete arches based on lumped damage mechanics, Int. J. Solids Struct., 50(24), pp. 4070-9, Doi: 10.1016/j.ijsolstr.2013.08.012.

[21] Amorim, DLNF, Proença, S.P.B., Flórez-López, J. (2014). Simplified modeling of cracking in concrete: Application in tunnel linings, Eng. Struct., 70, pp. 23-35, DOI: 10.1016/j.engstruct.2014.03.031.

[22] Brito, T.I.J., Santos, D.M., Santos, F.A.S., Cunha, R.N., Amorim, D.L.N.F. (2020) On the lumped damage modelling of reinforced concrete beams and arches, Frattura ed Integrità Strutturale, 54, pp. 1-20, DOI: 10.3221/IGF-ESIS.54.01

[23] Yang T. -S., Wang J. -L. (2010). Damage analysis of three-dimensional frame structure suffering from impact. J Vib Shock, 29(12), pp. 177-180.

[24] Teles, D.V.C., Oliveira, M.C., Amorim, D.L.N.F. (2020). A simplified lumped damage model for reinforced concrete beams under impact loads, Eng. Struct., 205, DOI: 10.1016/j.engstruct.2019.110070.

[25] Oliveira MC, Teles DVC, Amorim DLNF. (2020). Shear behaviour of reinforced concrete beams under impact loads by the Lumped Damage framework. Frattura ed Integrità Strutturale, 53, pp. 13-25, DOI: 10.3221/IGF-ESIS.53.02. 
[26] Brazilian Association of Technical Standards (ABNT). (2017). NBR 16605: Portland cement and other powdered material - Determination of the specific gravity.

[27] Brazilian Association of Technical Standards (ABNT). (2009). NBR NM 52: Fine aggregate - Determination of the bulk specific gravity and apparent specific gravity.

[28] Brazilian Association of Technical Standards (ABNT). (2003). NBR NM 248: Aggregates - Sieve analysis of fine and coarse aggregates.

[29] Brazilian Association of Technical Standards (ABNT). (2019). NBR NM 53: Coarse aggregate - Determination of the bulk specific gravity, apparent specific gravity and water absorption.

[30] e-composites. Tecido de Fibra de Vidro Unidirecional VEW130. Available at: http://www.marinecomposites.com.br/wp-content/uploads/datasheets/tecido_de_vidro_vew130.pdf.

[31] Rodrigues, P. P. F. (1995). Parâmetros de dosagem do concreto, São Paulo, ABCP.

[32] Brazilian Association of Technical Standards (ABNT). (2020). NBR NM 67: Fresh concrete - Slump test.

[33] Brazilian Association of Technical Standards (ABNT). (2016). NBR 5738: Concrete - Procedure for molding and curing concrete test specimens.

[34] Brazilian Association of Technical Standards (ABNT). (2018). NBR 5739: Concrete - Compression test of cylindrical specimens.

[35] Lemaitre J, Chaboche JL (1985). Mécaniques des matériaux solides. Paris: Dunod. ISBN: 978-2100013975.

[36] Brazilian Association of Technical Standards (ABNT). (2014). NBR 6118: Design of concrete structures - Procedure. 